\title{
Disability or Permanent Damage
}

National Cancer Institute

\section{Source}

National Cancer Institute. Disability or Permanent Damage. NCI Thesaurus. Code C102451.

A sustained and substantial impairment or disruption of a person's ability to conduct normal life functions for the remainder of his/her life. 